\title{
HIV Prevalence among Pregnant Women in Brazil: A National Survey
}

\section{Prevalência de HIV em grávidas brasileiras: pesquisa nacional}

\author{
Gerson Fernando Mendes Pereira ${ }^{1}$ Meritxell Sabidó ${ }^{2,3,4}$ Alessandro Caruso ${ }^{1}$ \\ Silvano Barbosa de Oliveira ${ }^{1}$ Fábio Mesquita ${ }^{1}$ Adele Schwartz Benzaken ${ }^{1,2}$
}

${ }^{1}$ Department of STI, AIDS and Viral Hepatitis, Secretariat of Health

Surveillance. Brazil Ministry of Health, Brasília, Brazil

2 Department of HIV, Tropical Medicine Foundation Doutor Heitor

Vieira Dourado (FMT-HVD), Manaus, Amazonas, Brazil

${ }^{3}$ TransLab, Department of Medical Sciences, Universitat de Girona,

Catalunya, Spain

${ }^{4}$ CIBER Epidemiology and Public Health (CIBERESP), Madrid, Spain

Address for correspondence Meritxell Sabidó, MD, PhD, Fundação de Medicina Tropical Doutor Heitor Vieira Dourado; Avenida Pedro Teixeira 25, 69040-000-Manaus, AM, Brasil

(e-mail: xellsabido@gmail.com).

Rev Bras Ginecol Obstet 2016;38:391-398.

\begin{abstract}
Background This study was conducted to determine the seroprevalence of HIV among pregnant women in Brazil and to describe HIV testing coverage and the uptake of antenatal care (ANC).

Methods Between October 2010 and January 2012, a probability sample survey of parturient women aged 15-49 years who visited public hospital delivery services in Brazil was conducted. Data were collected from prenatal reports and hospital records. Dried blood spot (DNS) samples were collected and tested for HIV. We describe the agespecific prevalence of HIV infection and ANC uptake with respect to sociodemographic factors.

Results Of the 36,713 included women, 35,444 (96.6\%) were tested for HIV during delivery admission. The overall HIV prevalence was of $0.38 \%$ ( $95 \%$ confidence interval $[\mathrm{Cl}]: 0.31-0.48)$, and it was highest in: the 30 to 39 year-old age group $(0.60 \%$ [0.40$0.88])$, in the Southern region of Brazil (0.79\% [0.59-1.04]), among women who had not completed primary $(0.63 \%$ [0.30-1.31]) or secondary $(0.67 \%$ [0.49-0.97]) school education, and among women who self-reported as Asian (0.94\% [0.28-3.10]). The HIV testing coverage during prenatal care was of $86.6 \%$ for one test and of $38.2 \%$ for two tests. Overall, $98.5 \%$ of women attended at least 1 ANC visit, $90.4 \%$ attended at least 4 visits, $71 \%$ attended at least 6 visits, and $51.7 \%$ received ANC during the 1 st trimester.

Keywords

- HIV

- pregnancy

- epidemiology

- Brazil HIV testing coverage and ANC uptake indicators increased with increasing age and education level of education, and were highest in the Southern region.

Conclusions Brazil presents an HIV prevalence of less than $1 \%$ and almost universal coverage of ANC. However, gaps in HIV testing and ANC during the first trimester challenge the prevention of the vertical transmission of HIV. More efforts are needed to address regional and social disparities.
\end{abstract}

received

March 5, 2016

accepted

July 14, 2016

published online

August 31, 2016
DOI http://dx.doi.org/

10.1055/s-0036-1592102. ISSN $0100-7203$.
Copyright $@ 2016$ by Thieme Publicações License terms

Ltda, Rio de Janeiro, Brazil
(요 (1) $\odot$ 


\section{Resumo}

\section{Palavras-chave \\ - HIV \\ - gravidez \\ - epidemiologia \\ - Brasil}

Introdução Este estudo foi realizado com o objetivo de determinar a soroprevalência do HIV entre as mulheres grávidas no Brasil e descrever a cobertura de exames de HIV e a integração dos cuidados pré-natais (CPN).

Métodos Entre outubro de 2010 e janeiro de 2012, foi realizada uma pesquisa de probabilidade por amostragem direcionada a mulheres grávidas com idade entre 15 e 49 anos, que utilizaram serviços de parto em hospitais públicos do Brasil. Os dados foram coletados a partir de relatórios pré-natais e registros hospitalares. Amostras de sangue foram coletadas e submetidas a exames de HIV. Descrevemos a prevalência da infecção pelo HIV específica de acordo com a idade e a absorção dos CPN em relação a fatores demográficos.

Resultados Das 36.713 mulheres incluídas, 35.444 (96,6\%) foram submetidas a exames de HIV durante a admissão para o trabalho de parto. A prevalência global de HIV foi de $0,38 \%$ (intervalo de confiança [IC] de $95 \%$ : $0,31-0,48$ ), e foi maior no grupo com a faixa etária entre 30 e 39 anos de idade $(0,60 \%[0,40-0,88])$, da região Sul $(0,79 \%[0,59-1,04])$, entre as mulheres com o ensino fundamental incompleto $(0,63 \%$ $[0,30-1,31])$ ou ensino médio incompleto $(0,67 \%[0,49-0,97])$, e entre as mulheres que se identificam como asiáticas $(0,94 \%[0,28-3,10])$. A cobertura do exame de HIV durante os CPN foi de $86,6 \%$ para um exame e de $38,2 \%$ para dois exames. No geral, $98,5 \%$ das mulheres foram atendidas em pelo menos 1 consulta de CPN, 90,4\% compareceram a pelo menos 4 consultas, $71 \%$ compareceram a pelo menos 6 visitas, e $51,7 \%$ receberam CPN durante o $1^{\circ}$ trimestre. A cobertura de exames de HIV e os indicadores de captação de CPN aumentaram de forma proporcional ao aumento da idade e do nível de educação, e foram maiores na região Sudeste.

Conclusões O Brasil apresenta uma prevalência de menos de $1 \%$ e cobertura praticamente universal de CPN. No entanto, as lacunas nos exames de HIV e CPN durante o primeiro trimestre representam um desafio à prevenção contra a transmissão vertical do HIV. São necessários mais esforços a fim de reduzir as disparidades regionais e sociais.

\section{Introduction}

Brazil has an HIV/AIDS epidemic that is stable at the national level and concentrated in key populations. ${ }^{1}$ Nevertheless, Brazil has the largest number of people living with HIV/AIDS in Latin America, with 798,366 recorded AIDS cases as of June 2015 and $\sim$ 40,600 new cases each year. ${ }^{2}$ The AIDS mortality rate has decreased in Brazil over the last ten years, ${ }^{3}$ and was of 5.7/100,000 inhabitants in 2014. ${ }^{2}$ Despite recent efforts to expand antiretroviral treatment (ART), ${ }^{4}$ ART coverage, at $74.6 \%$ in $2015,{ }^{1}$ requires further improvement.

Regarding HIV-infected pregnant women, 63.9\% received ART to reduce mother-to-child transmission (MTCT) of HIV, ${ }^{1}$ which is the main source of HIV infection in children in Brazil. In 2013,14,352 children under 13 years were living with HIV in this country, $92.6 \%$ of whom had acquired HIV through MTCT. ${ }^{5}$ Brazil issued the first recommendations on the prevention of mother-to-child transmission (PMTCT) of HIV in 1996.,7 These recommendations were revised in 2007 with the adoption of combination ART prophylaxis for women not eligible for lifelong ART. ${ }^{8}$ In 2010, the guidelines were updated to offer lifelong ART to all HIV-infected pregnant women regardless of their CD4 count. $^{9}$ In 2011, the Stork Network Initiative was established to strengthen antenatal care (ANC) and to expand rapid testing for syphilis and HIV in ANC services. ${ }^{10}$

The Brazilian government has conducted periodic and anonymous probability sample surveys to determine the HIV prevalence among parturient women utilizing public sector delivery clinics since the year $1996 .{ }^{11-15}$ Data from these surveillance rounds have been used to monitor HIV infection among pregnant women. Moreover, the data have been used as a proxy to estimate the prevalence of HIV among adults in the general population, ${ }^{16}$ to make projections about HIV incidence that are helpful for resource allocation, and to evaluate the effectiveness of the national surveillance system in identifying HIV cases among pregnant women. ${ }^{17,18}$ In each survey, women were tested for HIV, ${ }^{11,13-15}$ except for the 2006 round, in which HIV prevalence was obtained from routinely collected data. ${ }^{12}$ The study also monitors the coverage of HIV testing, knowledge of HIV status before giving birth, and participation in ANC.

The objective of this study was to determine HIV prevalence among pregnant women in Brazil. In addition, we describe the coverage of HIV testing and participation in ANC interventions. 


\section{Methods}

\section{Study Design}

Between October 2010 and January 2012, we conducted a cross-sectional survey using a probability sample of parturient women recruited at hospital delivery public services from the Unified Health System (Sistema Único de Saúde, SUS) in Brazil. The National Commission for Ethics in Research (CONEP) approved this study (approval number: 709/2009).

\section{Sample Size}

The sample size was calculated based on the objective of estimating the prevalence of HIV among pregnant women in Brazil and its regions. Considering the prevalence of HIV among parturient women in $2006(0.41 \%),{ }^{12}$ a 95\% confidence interval $(\mathrm{CI})$ with a margin of error no greater than $0.15 \%$, a design effect of 1.1 , and an estimated loss to followup of $10 \%$, the required sample size was calculated to be at least of 40,000 parturient women ( 8,000 in each region).

\section{Sampling Strategy}

A stratified two-stage cluster sampling design was used. In the initial stage of sample selection, 219 public hospital maternity services with at least 500 deliveries in 2007 were used as the primary sampling unit. Maternity services were stratified according to region (North, Northeast, Southeast, South, Central-West) and the population size of the municipality ( $<50,000$; 50,001 to 400,000; and $\geq 400,001$ inhabitants) in which each service was located. In each stratum, 15 maternity services were selected by a probability proportional to the number of admissions for delivery in 2007. Finally, within each maternity service, 180 to 200 pregnant women were randomly selected upon admission for delivery.

\section{Study Population and Procedures}

Pregnant women admitted for delivery were included in the study if they were 15-49 years of age and had signed a written consent form to participate. Parental informed consent was not required for women younger than 18 years of age. In Brazil, according to law CFM n ${ }^{\circ} 1.865 / 96$, HIV testing under 18 years of age is voluntary and consented to by the adolescent, without the need to obtain authorization or consent from their parents or their legal guardian. Trained health care workers completed a structured questionnaire that included sociodemographic variables, the date and number of ANC visits, and the date and results of HIV tests. Data were automatically recorded using the TeleForm 10.2 software (Cardiff Software Inc., Solana Beach, CA, USA).

Health professionals collected 8 drops of finger-prick blood using S\&S 903 sample collection cards (Schleicher \& Schuell BioScience, Keene, NH, USA). The dried blood spot (DBS) samples were sent, by mail, in ziplock plastic bags with desiccant silica to the HIV/AIDS Research Laboratory of Universidade de Caxias do Sul and stored at room temperature. Dried blood spot samples were tested using an enzymelinked immunosorbent assay (ELISA [Q-Preven HIV $1+2$ DBS, Symbiosis Diagnóstica, Leme, Brazil]). All positive results were confirmed with a second ELISA and Western blot analysis (DAVIH-BLOT, Laboratorios DAVIH, La Habana, Cuba). All women were informed of their tests results.

\section{Data Analyses}

HIV testing coverage during pregnancy was defined as the proportion of pregnant women among parturient women admitted for delivery who received ANC and who had an HIV test result documented in their prenatal reports. HIV testing participation during delivery admission was defined as the proportion of parturients who underwent an HIV test. HIV prevalence was defined as the number of women with positive HIV test results among parturient women admitted for delivery. Participation in ANC was classified as attending at least one, four, or six ANC visits, according to international indicators. The prevalence was calculated for the overall sample and stratified by age, region, and level of education. For women $<24$ years of age, the HIV prevalence was analyzed by two-year age bands. We used the exact method to generate the confidence intervals of prevalence estimates. All analyses were conducted with the complex survey functions of Stata 11 (StataCorp LP, College Station, TX, USA) and incorporated weighting, clustering (because clinics with different sizes were included), and stratification of data.

\section{Results}

\section{Demographic Characteristics}

Of the estimated sample size of 40,000 participants, 38,393 (96\%) parturient women were included. Of those, 1,680 were excluded (4.4\%) due to the lack of municipality information, which was important for the calibration of the sample, the absence of a signed informed consent form, or missing blood samples. Therefore, 36,713 pregnant women attending prenatal clinics across Brazil were included in the HIV prevalence survey. The proportion of women in the 15-19 year-old age group was $20.6 \%$; $5.5 \%$ of participants had not completed primary school; $39.9 \%$ of participants lived in the Southeast region, and $51.2 \%$ of the participants self-reported as being of mixed race.

\section{Coverage of HIV Testing during Prenatal Care}

- Table 1 shows coverage of HIV testing during prenatal care for the overall sample and stratified by sociodemographic characteristics. Overall, 86.6\% (95\% CI: 86.1-87) of pregnant women received an HIV test, and 38.2\% (95\% CI: 37.6-38.9) were tested twice. Coverage for HIV testing increased with increasing age, ranging from 83.8\% (95\% CI: 82.8-84.8) among women aged $15-24$ years to $88.1 \%$ (95\% CI: $85.1-$ 90.6) among those aged 40-49 years. The coverage of two HIV tests followed a similar pattern, ranging from $34.9 \%$ (95\% CI: $33.5-36.4$ ) in the 15-19 year-old age group to $43.9 \%$ (95\% CI: 38.9-49.1) in the 40-49 year-old age group. Regarding the region, the South region showed the highest coverage of HIV testing for at least one and for two HIV tests, 96.2\% (95\% CI: 95.8-96.7) and 58.8\% (95\% CI: 57.6-60) respectively. The Northern and Northeast regions showed the lowest coverage for at least one HIV test (75.3\% [95\% CI: 74.1-76.4] and 74.1\% [95\% CI: 73.1-75.2] respectively) and for two HIV tests (19.6\% [95\% CI: 18.6-20.7] and 22.3\% [95\% CI: 21.2-23.4] 
Table 1 Coverage of HIV testing and HIV prevalence among parturient women in the public sector in Brazil according to sociodemographic factors

\begin{tabular}{|c|c|c|c|c|c|c|}
\hline & \multicolumn{2}{|c|}{$\begin{array}{l}\text { HIV testing coverage } \\
\text { during prenatal care }\end{array}$} & \multicolumn{2}{|c|}{$\begin{array}{l}2^{\text {nd }} \text { HIV testing coverage } \\
\text { during prenatal care }\end{array}$} & \multicolumn{2}{|c|}{ HIV prevalence } \\
\hline & $\mathrm{N}$ & $\%(95 \% \mathrm{Cl})$ & $\mathrm{N}$ & $\%(95 \% \mathrm{Cl})$ & $\mathrm{N}$ & $\%(95 \% \mathrm{CI})$ \\
\hline Total & 36,016 & $86.6(86.1-87)$ & 34,546 & $38.2(37.6-38.9)$ & 36,713 & $0.38(0.31-0.48)$ \\
\hline \multicolumn{7}{|l|}{ Age in years } \\
\hline $15-19$ & 8,054 & $83.8(82.8-84.8)$ & 7,742 & $34.9(33.5-36.4)$ & 8,213 & $0.32(0.18-0.58)$ \\
\hline $20-24$ & 11,098 & $85.3(84.5-86.1)$ & 10,660 & $37.3(36-38.5)$ & 11,325 & $0.30(0.19-0.47)$ \\
\hline $25-29$ & 8,681 & $87.7(86.8-88.5)$ & 8,303 & $39(37.6-40.4)$ & 8,837 & $0.35(0.22-0.56)$ \\
\hline $30-39$ & 7,500 & $89.4(88.6-90.2)$ & 7,190 & $41.2(39.7-42.7)$ & 7,648 & $0.60(0.40-0.88)$ \\
\hline $40-49$ & 683 & 88.1 (85.1-90.6) & 651 & $43.9(38.9-49.1)$ & 690 & $0.32(0.11-0.93)$ \\
\hline \multicolumn{7}{|l|}{ Region } \\
\hline North & 7,136 & $75.3(74.1-76.4)$ & 7,015 & $19.6(18.6-20.7)$ & 7,236 & $0.36(0.22-0.57)$ \\
\hline Northeast & 7,046 & $74.1(73.1-75.2)$ & 6,740 & $22.3(21.2-23.4)$ & 7,377 & $0.24(0.14-0.41)$ \\
\hline Southeast & 8,130 & 94.3 (93.8-94.9) & 7,667 & $45.4(44-46.8)$ & 8,211 & $0.37(0.23-0.58)$ \\
\hline South & 8,114 & $96.2(95.8-96.7)$ & 7,807 & $58.8(57.6-60)$ & 8,192 & $0.79(0.59-1.04)$ \\
\hline Central-West & 5,590 & $91.2(90-92.4)$ & 5,317 & $51.1(48.9-53.2)$ & 5,697 & $0.38(0.17-0.85)$ \\
\hline \multicolumn{7}{|l|}{ Educational level } \\
\hline Incomplete primary school & 2,297 & $73.1(70.8-75.3)$ & 2,194 & $28.8(26.3-31.5)$ & 2,341 & $0.63(0.30-1.31)$ \\
\hline Incomplete secondary school & 10,722 & $81.9(81-82.8)$ & 10,233 & $32.7(31.5-33.9)$ & 10,909 & $0.67(0.49-0.97)$ \\
\hline $\begin{array}{l}\text { Incomplete post-secondary } \\
\text { school }\end{array}$ & 9,947 & $87.6(86.7-88.3)$ & 9,520 & $39.7(38.4-41)$ & 10,235 & $0.28(0.18-0.44)$ \\
\hline $\begin{array}{l}\geq \text { complete post-secondary } \\
\text { school }\end{array}$ & 12,250 & $91.2(90.6-91.8)$ & 11,839 & $42.4(41.3-43.6)$ & 12,403 & $0.38(0.30-0.48)$ \\
\hline \multicolumn{7}{|l|}{ Race/color } \\
\hline White & 12,211 & $92.5(91.9-93.1)$ & 11,862 & $47.1(45.9-48.3)$ & 12,371 & $0.33(0.23-0.48)$ \\
\hline Black & 3,764 & $84.6(83.2-85.8)$ & 3,607 & $34.6(32.6-36.7)$ & 3,851 & $0.80(0.49-1.29)$ \\
\hline Asian & 555 & $84.6(80.5-87.9)$ & 521 & $35.8(30.8-41.2)$ & 560 & $0.94(0.28-3.10)$ \\
\hline Brown & 17,897 & $83.6(83-84.3)$ & 17,065 & $33.6(32.6-34.5)$ & 18,304 & $0.29(0.20-0.42)$ \\
\hline Indigenous & 435 & $72(66.1-77.3)$ & 430 & $26.4(20.6-33.2)$ & 445 & $0.34(0.05-2.36)$ \\
\hline
\end{tabular}

respectively). HIV testing increased with increasing level of education for both indicators. Regarding race/color, HIV testing was highest in women self-reporting as white, and was estimated at 92.5\% (95\% CI: 91.9-93.1) for at least one HIV test, and at $47.1 \%$ (95\% CI: 45.9-48.3) for two HIV tests.

\section{HIV Prevalence}

Overall, 96.8\% of women (95\% CI: 96.5-97) received an HIV test during delivery admission. HIV testing participation remained constant across age groups, ranging from $96.2 \%$ (95\% CI: 94.1-97.6) in women aged 40-49 years to 97\% (95\% CI: 96.5-97.4) in those aged 20-24 years. - Table 1 shows the overall HIV prevalence and the prevalence according to sociodemographic characteristics. Overall, 126 women were HIV positive, resulting in an HIV prevalence of $0.38 \%$ (95\% CI: 0.31-0.48). The prevalence was highest in the 30-39 year-old age group, at 0.60\% (95\% CI: 0.40-0.88). - Table 2 presents the HIV prevalence in young women $\leq 24$ years of age in two-year age groups. In the $\leq 16$ year-old age group, the estimated HIV prevalence was at 0.22 (95\% CI: 0.05-1), but it rapidly increased to 0.40 (95\% CI: $0.19-0.86$ ) in those 17-18 years old and decreased thereafter, with values of

Table 2 HIV prevalence among $\leq 24$-year-old parturient women delivering in the public sector in Brazil

\begin{tabular}{|l|l|l|}
\hline Age in years & $\mathrm{n} / \mathrm{N}$ & $\begin{array}{l}\text { HIV prevalence } \\
\%(95 \% \mathrm{CI})\end{array}$ \\
\hline$\leq 16$ & $2 / 2,067$ & $0.22(0.05-1)$ \\
\hline $17-18$ & $9 / 3,814$ & $0.40(0.19-0.86)$ \\
\hline $19-20$ & $13 / 4,747$ & $0.37(0.19-0.72)$ \\
\hline $21-22$ & $12 / 4,657$ & $0.25(0.13-0.51)$ \\
\hline $23-24$ & $10 / 4,253$ & $0.27(0.12-0.61)$ \\
\hline Total & $46 / 19,538$ & $0.31(0.22-0.44)$ \\
\hline
\end{tabular}


$0.37 \%$ (95\% CI: 0.19-0.72) in the 19-20 year-old age group, and of $0.27 \%$ (95\% CI: $0.12-0.61)$ in the $23-24$ year-old age group. By region ( $\mathbf{- T a b l e ~} \mathbf{1}$ ), the HIV prevalence ranged from $0.24 \%$ (95\% CI: $0.14-0.41$ ) in the Northeast to $0.79 \%$ (95\% CI: 0.59-1.04) in the South. HIV prevalence was highest among women with lower educational levels and was $0.63 \%$ (95\% CI: $0.30-1.31$ ) among women who had not completed primary school. Women self-reporting as Asian and black showed the highest HIV prevalence, $0.94 \%$ (95\% CI: $0.28-3.10$ ) and $0.80 \%$ (95\% CI: 0.49-1.29) respectively.

\section{Coverage of Antenatal Care}

- Fig. 1 shows the ANC coverage and percentage of pregnant women receiving ANC during the first trimester, overall and stratified by age. Overall, an estimated 98.5\% (95\% CI: 98.498.7) of pregnant women in Brazil attended at least 1 ANC visit, 90.4\% (95\% CI: 90-90.7) attended 4 or more ANC visits, and $71 \%(95 \% \mathrm{CI}: 70.3-71.6)$ attended 6 or more ANC visits. Overall, 51.7\% (95\% CI: 51-52.4) attended their first ANC visit during the first trimester. An age-stratified analysis showed that the coverage of ANC visits and ANC during the first trimester were lowest in women $<20$ years old, with estimated values of $98.6 \%$ (95\% CI: 98.2-98.9) for at least 1 visit, 87.8\% (95\% CI: 86.7-88.7) for $\geq 4$ visits, 65.7\% (95\% CI: 64.367.1 ) for $\geq 6$ visits, and $44.9 \%$ (95\% CI: 43.4-46.4) for the first ANC visit during the first trimester, and ANC visits remained stable across the 20 to 49 years of age groups. - Table 3 shows ANC coverage and the proportion of women who received ANC during the first trimester by region, level of education, and race/color. The North region presented a lower coverage of each indicator when compared to any of the other country regions, with an estimated $96.6 \%$ of pregnant women with at least 1 ANC visit, $84.3 \%$ with at least 4 visits, $55.7 \%$ with at

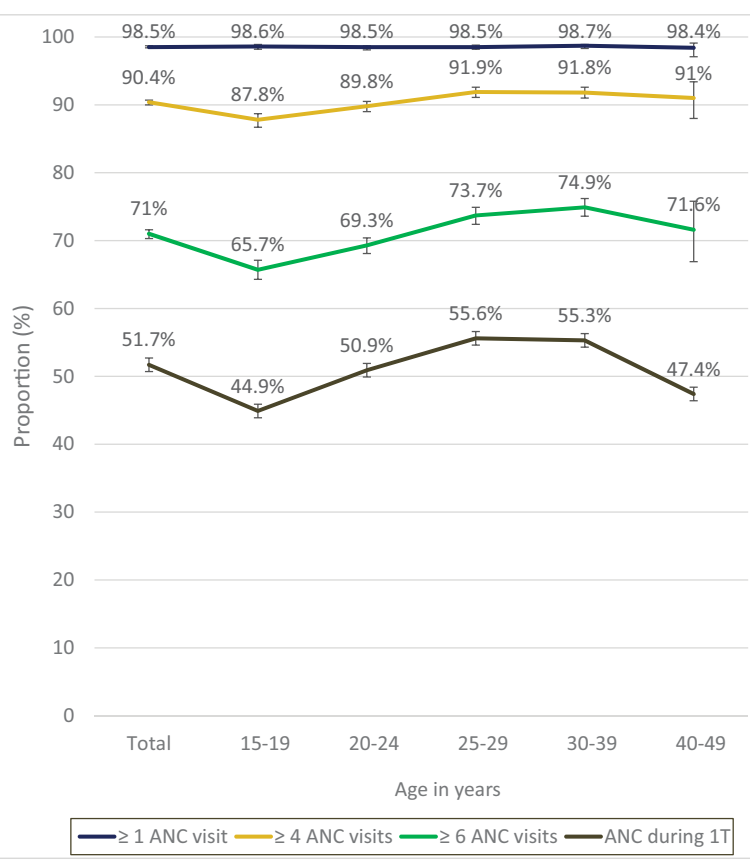

Fig. 1 Antenatal care among pregnant women in the public sector in Brazil according to age. least 6 visits, and 40.5\% receiving ANC during the first trimester. The coverage of ANC increased progressively with increasing levels of education, along with the proportion of women who received ANC during the first trimester. The percentage of women attending at least one ANC visit was similar across different races, while the percentages of those attending at least four and at least six ANC visits were highest in pregnant women self-reporting as white $(92.2 \%$ and $76.4 \%$ respectively) and lowest in the indigenous population (78.7\% and $52.9 \%$ respectively).

\section{Discussion}

In our large and probabilistic antenatal care-based study, we found an HIV prevalence of $0.38 \%$. This value classifies Brazil as having a concentrated epidemic (HIV prevalence $<1 \%$ in the general population), ${ }^{19}$ but it hides regional variations. HIV prevalence in the South region is twice that of the national estimate. This region has consistently presented the highest estimates in the country for HIV surveillance indicators. In 2012, the AIDS detection rate was reported at 30.9 cases $/ 100,000$ inhabitants, and the mortality rate was 7.7 deaths $/ 100,000$ inhabitants, which is higher than that of the country (20.2 cases/100,000 inhabitants and 5.5 deaths/ 100,000 inhabitants respectively). ${ }^{1}$

The prevalence of HIV among young people (15-24 years of age) is one of the leading indicators of progress toward international goals, such as those set in the United Nations General Assembly Special Sessions (UNGASS) declaration on HIV/AIDS. ${ }^{19}$ The HIV prevalence in this age group was of $0.31 \%$, which is lower than the overall estimate for the country. The HIV prevalence in 15-24 year-olds is considered a reliable measurement to approximate HIV incidence because this population can be presumed to have recently become sexually active. ${ }^{20,21}$ In our study, the $17-18$ year-old age group presented a burden of potential HIV incidence of $0.40 \%$, which is higher than the rate in pregnant women in the 15-24 year-old age group. HIV acquisition in this group reflects sexual initiation, which occurs at $\sim 16$ years of age, ${ }^{22}$ and is a concern if we assume that HIV transmission is highest during early and acute HIV infection. Changing the HIV epidemic burden in this group will require prevention and interventions targeted at teenagers.

We found an HIV prevalence similar to the prevalence of $0.41 \%$ estimated in $2006 .^{12}$ In that prior HIV survey, the HIV prevalence in childbearing women was estimated based on secondary data registered in prenatal reports or hospitalization records from public maternity hospitals. Although different methods were used in this prior survey and the current study (with values determined in 2006 based on routinely collected data, and in 2010-2012 based on testing women for HIV), similar results were obtained. These results indicate that HIV prevalence appears to be stable despite a continuing increase in ART coverage. The HIV detection rate among pregnant women in Brazil has exhibited an increasing trend during the preceding three years. ${ }^{2}$ In 2013, the observed rate was 2.4 cases per 1,000 live births, which increased to 2.6 in 2015. In contrast, the vertical 
Table 3 Coverage of ANC and proportion of pregnant women receiving ANC during the first trimester according to sociodemographic characteristics

\begin{tabular}{|c|c|c|c|c|c|c|c|}
\hline & $\mathbf{n}$ & $\begin{array}{l}\geq 1 \text { ANC visit } \\
\%(95 \% \mathrm{Cl})\end{array}$ & $\mathbf{n}$ & $\begin{array}{l}\geq 4 \text { ANC visits } \\
\%(95 \% \mathrm{Cl})\end{array}$ & $\begin{array}{l}\geq 6 \text { ANC visits* } \\
\%(95 \% \mathrm{Cl})\end{array}$ & $\mathbf{n}$ & $\begin{array}{l}\text { ANC during } 1 \mathrm{~T} \\
\%(95 \% \mathrm{CI})\end{array}$ \\
\hline \multicolumn{8}{|l|}{ Region } \\
\hline North & 7,233 & 96.3 (95.7-96.7) & 6,864 & $84.3(83.2-85.3)$ & $55.7(54.3-57.1)$ & 6,888 & $40.5(39.1-41.8)$ \\
\hline Northeast & 7,370 & $97.6(97.2-98)$ & 6,806 & $87.7(86.8-88.6)$ & $63.3(62-64.5)$ & 6,850 & $47.5(46.2-48.7)$ \\
\hline Southeast & 8,210 & 99.5 (99.2-99.6) & 8,074 & $92.9(92.1-93.5)$ & $77.2(76.1-78.3)$ & 7,974 & $55.5(54.1-56.8)$ \\
\hline South & 8,192 & 99.6 (99.4-99.7) & 8,080 & $94(93.4-94.6)$ & $81.1(80.1-82)$ & 8,001 & $57.5(56.3-58.6)$ \\
\hline Central-West & 5,696 & 98.7 (98.2-99.1) & 5,461 & $88.8(87.5-90)$ & 69 (67.1-70.9) & 5,457 & $53.6(51.5-55.7)$ \\
\hline \multicolumn{8}{|l|}{ Educational level } \\
\hline $\begin{array}{l}\text { Incomplete } \\
\text { primary school }\end{array}$ & 2,339 & $97.1(96-97.9)$ & 2,213 & $82.3(80-84.2)$ & $59.4(56.7-62)$ & 2,208 & $42.1(39.4-44.8)$ \\
\hline $\begin{array}{l}\text { Incomplete } \\
\text { secondary } \\
\text { school }\end{array}$ & 10,904 & $98.1(97.7-98.4)$ & 10,463 & $86.6(85.7-87.5)$ & $63.9(62.7-65.2)$ & 10,439 & $45.7(44.4-47)$ \\
\hline $\begin{array}{l}\text { Incomplete } \\
\text { post-secondary } \\
\text { school }\end{array}$ & 10,234 & $98.2(97.7-98.6)$ & 9,784 & $90.9(90.1-91.2)$ & $71.4(70.2-72.6)$ & 9,752 & $52.1(50.8-53.5)$ \\
\hline $\begin{array}{l}\geq \text { complete } \\
\text { post-secondary } \\
\text { school }\end{array}$ & 12,400 & 99.3 (99.2-99.5) & 12,051 & $93.9(93.3-94.4)$ & $77.2(76.2-78.2)$ & 5,066 & $57.1(55.9-58.3)$ \\
\hline \multicolumn{8}{|l|}{ Race/color } \\
\hline White & 12,371 & 99.3 (99.1-99.4) & 12,074 & $92.2(91.5-92.9)$ & $76.4(75.3-77.4)$ & 12,003 & $56.7(55.5-58)$ \\
\hline Black & 3,846 & 96.3 (95.6-97) & 3,579 & $88.6(87.2-90)$ & 67 (65-68.9) & 3,616 & $47(44.9-49.1)$ \\
\hline Asian & 560 & 98.8 (96.9-99.6) & 544 & $88.4(84.3-91.6)$ & $71.7(66.6-76.2)$ & 546 & $53.1(47.7-58.3)$ \\
\hline Brown & 18,299 & 98.7 (98.5-98.7) & 17,535 & $89.8(89.3-90.4)$ & $68.6(67.7-69.5)$ & 17,497 & $49.8(48.8-50.8)$ \\
\hline Indigenous & 445 & 99.3 (98.5-99.7) & 423 & 78.7 (72.6-83.7) & $52.9(45.8-60)$ & 423 & $37(30.4-44.2)$ \\
\hline
\end{tabular}

Abbreviations: 1T, first trimester; ANC, antenatal care.

*same $\mathrm{N}$ as $\geq 4$ ANC visits.

transmission rate has decreased during the prior three years; in particular, this rate has diminished, from 3.4 cases per 100,000 inhabitants in 2013 to 2.8 cases $/ 100,000$ inhabitants in $2015 .^{2}$ This trend suggests the success of the strategy of working together with prenatal services to identify and appropriately monitor HIV-positive mothers. Similarly, detection rates in adults fell from 21.1/100,000 inhabitants in 2012 to $19.7 / 100,000$ inhabitants in $2014 .^{2}$ Mortality rates are stable at the country level, but have decreased in certain states. ${ }^{2}$ With respect to the continuum of care, from 2014 to 2015, Brazil experienced a reduction in the population of HIV-positive individuals who have never been tested. ${ }^{2}$ Importantly, more patients have initiated treatment, including $74.6 \%$ of all eligible adults and children. ${ }^{1}$ Moreover, adherence to treatment has improved, and suppression of viral load has approached the goal that countries around the world have established for $2020 .^{2}$

The HIV test coverage during pregnancy was of $86.6 \%$, which is higher than the $74 \%$ estimated for Latin America and the Caribbean in 2013. ${ }^{23}$ However, improvement is required to attain the coverage rate of $95 \%$ proposed by the Pan American Health Organization (PAHO) for the Latin American and Caribbean region for a vertical transmission control program. ${ }^{24}$
Coverage of HIV testing has increased substantially since 2006 (62.3\%). ${ }^{12}$ The coverage improved in each region, but inequalities persist, with the North and Northeast regions presenting lower coverage estimates of $75.3 \%$ and $74.1 \%$ respectively. The geographical inequalities in testing coverage and in HIV prevalence are reflected in the MTCT rate for HIV, which varies across the country. The most recent estimates are higher for northern Brazil, ranging from $6.6 \%$ to $18.9 \%,{ }^{25-27}$ than for the south of the country, at $4.9 \% .^{28}$

Only $38.2 \%$ of pregnant women underwent a second serological test for HIV. This second test is indicated in the third trimester, and was introduced in 2006 as part of a prenatal care routine. ${ }^{29}$ The low coverage observed may be partly attributed to the fact that only $40.5 \%$ of women received ANC during the first trimester, which limits timely opportunities to perform a second test and to initiate strategies to prevent the vertical transmission of HIV.

Access to antenatal services in Brazil is high, with > 95\% of pregnant women attending at least one ANC visit. While coverage of one ANC visit is practically universal, fewer women are covered when more meaningful and comprehensive ANC, consisting of four or more ANC visits or the national recommendation of six or more visits, is considered. The 
insufficient number of ANC consultations may be due to late presentation to ANC, issues with the quality of ANC, and/or failure to follow-up by the pregnant women. ${ }^{23}$

The burden of HIV infection and lack of coverage of indicators, both for HIV testing and ANC visits, in women with lower educational levels and who are non-white, is concerning. Although Brazil has universal access to interventions to prevent the MTCT of HIV, it is failing to reach the lower social strata of society. Other studies have corroborated the association between socioeconomically and educationally disadvantaged women and lower levels of access to HIV prevention measures during pregnancy. ${ }^{30-32}$

The study has several limitations. The extent to which pregnant women attending antenatal clinics are representative of all women is affected by attendance at private clinics, and is due to systematic differences among women who attend public ANC clinics, who have a lower socioeconomic status, and those who attend private clinics. In a national hospital-based study conducted on puerperal women in 2012, the HIV prevalence differed according to type of delivery service $(0.10 \%$ in private hospitals and $0.58 \%$ in public hospitals). ${ }^{30}$ In Brazil, more than 99\% of deliveries occur in hospitals, and therefore non-attendance at ANC clinics might not have affected our estimates. ${ }^{33} \mathrm{HIV}$ in Brazil is prevalent among older women who experience lower fertility rates and thus are less likely to be represented among ANC clinic attendees. ${ }^{34,35}$ Antiretroviral treatment may ameliorate HIV-related subfertility; ${ }^{34}$ thus, with increasing high levels of ART coverage, HIV rates among older pregnant women may again become more similar to those of the general population. ${ }^{36}$ Our study did not consider other factors that could influence the representativeness of HIV prevalence among ANC attendees, such as contraceptive use. ${ }^{20,21,37}$

In conclusion, our results indicate that the prevalence of HIV in Brazil remains at less than $1 \%$ and similar to that of 2006, despite the expanded population level coverage of ART. The results from the youngest group (aged 15-24 years) are encouraging, given the large investment in the prevention of HIV. Access to ANC services is universal, but more efforts are needed to increase the proportion of women who successfully complete at least six ANC visits, as recommended by the Brazilian Ministry of Health. Coverage of HIV testing has greatly increased since 2006 , and although it is $>80 \%$, it is subject to improvement because universal and free access to HIV testing is provided at ANC services. This finding, coupled with the fact that only half of women receive ANC care in the first trimester, results in missed opportunities to prevent the MTCT of HIV. Regional and social disparities in access to ANC clinics and HIV testing show that actions to overcome barriers for these services are not reaching the populations with a higher burden of HIV infection. Programs might consider ways to make these services more targeted to the North region and to socially disadvantaged populations, who are most at risk for HIV.

\section{Acknowledgments}

We thank the government officials, health professionals, and women who participated in the study.

\section{References}

1 Brazilian Ministry of Health. Secretariat of Health Surveillance. Department of STI, Aids and Viral Hepatitis [Internet]. The Brazilian response to HIV and AIDS: global AIDS response progress reporting: narrative report. Brasília (DF): Ministry of Health; 2015 [cited 2016 Apr 02]. Available from: http://www.unaids.org/sites/default/files/ country/documents/BRA_narrative_report_2015.pdf

2 Ministry of Health. Secretariat of Health Surveillance. Department of STI, AIDS, and Viral Hepatitis. [Internet][Epidemiological Bulletin AIDS and STI]. Brasillia (DF): Ministry of Health; 2015 [cited 2016 Apr 02]; Available from: http://www.aids.gov.br/sites/default/files/anexos/publicacao/2015/58534/boletim_aid-

s_11_2015_web_pdf_19105.pdf. Portuguese

3 Murray CJ, Ortblad KF, Guinovart C, et al. Global, regional, and national incidence and mortality for HIV, tuberculosis, and malaria during 1990-2013: a systematic analysis for the Global Burden of Disease Study 2013. Lancet 2014;384(9947):1005-1070

4 Ministry of Health. Secretariat of Health Surveillance. Department of STI, AIDS, and Viral Hepatitis. [Internet][Epidemiological Bulletin AIDS and STI]. Brasília (DF): Ministry of Health; 2014 [cited 2016 Apr 02]; Available from: http://www.aids.gov.br/ sites/default/files/anexos/publicacao/2014/56677/boletim_2014_final_pdf_15565.pdf. Portuguese

5 Ministry of Health. Secretariat of Health Surveillance. Department of STI, AIDS, and Viral Hepatitis. [Internet][Epidemiological Bulletin AIDS and STI]. Brasília (DF): Ministry of Health; 2013 [cited 2016 Apr 02]; Available from: http://www.aids.gov.br/ sites/default/files/anexos/publicacao/2013/55559/_p_boletim_2013_internet_pdf_p_51315.pdf. Portuguese

6 Connor EM, Sperling RS, Gelber R, et al. Reduction of maternalinfant transmission of human immunodeficiency virus type 1 with zidovudine treatment. Pediatric AIDS Clinical Trials Group Protocol 076 Study Group. N Engl J Med 1994;331(18):1173-1180

7 Brazil. Ministry of Health [Internet]. [Guide of therapeutic approaches in HIV/AIDS- 1996]. Brasília (DF): Ministry of Health; 1996 [cited 1996 Oct 31]. Available from: http://www.aids.gov.br/ sites/default/files/GUIA_DE_CONDUTAS_TERAPEUTICAS_EM_HIV_AIDS_-_1996.pdf. Portuguese

8 Brazilian Ministry of Health. Secretariat of Health Surveillance. National Program of STI and AIDS [Internet]. [Protocol for the prevention of vertical transmission of HIV and syphilis]. Brasília (DF): Ministry of Health; 2007 [cited 2014 Nov 16]. Available from: http://bvsms.saude.gov.br/bvs/publicacoes/protocolo_prevencao_transmissao_verticalhivsifilis_manualbolso.pdf. Portuguese

9 Brazilian Ministry of Health. Secretariat of Health Surveillance. Department of STI, Aids and Viral Hepatitis [Internet]. [Recommendations for the prevention of vertical transmission of HIV and antiretroviral therapy in pregnant women]. Brasília (DF): Ministry of Health; 2010 [cited 2010 Nov 16]. Available from: http://www. aids.gov.br/publicacao/consenso-recomendacoes-para-profilaxiada-transmissao-vertical-do-hiv-e-terapia-antirretr. Portuguese

10 Brazilian Ministry of Health. Secretariat of Health Surveillance. Department of STI, Aids and Viral Hepatitis [Internet]. [Progress report on the Brazilian response to HIV/AIDS (2010-2011)]. Brasília (DF): Ministry of Health; 2012 [cited 2015 Aug 03]. Available from: http://www.aids.gov.br/sites/default/files/anexos/publicacao/ 2012/51906/ungass_2012_portugues_rev_08jun_pdf_51895.pdf. Portuguese

11 Souza Júnior PR, Szwarcwald CL, Barbosa Júnior A, Carvalho MF, Castilho EA. [HIV infection during pregnancy: the Sentinel Surveillance Project, Brazil, 2002]. Rev Saude Publica 2004;38(6): 764-772. Portuguese

12 Szwarcwald CL, Barbosa Júnior A, Souza-Júnior PR, et al. HIV testing during pregnancy: use of secondary data to estimate 2006 test coverage and prevalence in Brazil. Braz J Infect Dis 2008; 12(3):167-172 
13 Szwarcwald CL, Souza Júnior PRB. [Estimate of HIV prevalence among Brazilian population aged 15-49 years, 2004]. Epidemiol Bull AIDS DST [Internet]. 2006 [cited 2015 Aug 03];3(1). Available from: http://www.aids.gov.br/sites/default/files/BOLETIM2006internet_0.pdf. Portuguese

14 Szwarcwald CL, Castilho EA. [Estimated number of HIV-infected individuals aged 15-49 years in Brazil, 1998]. Cad Saude Publica 2000;16(\#, Suppl 1)135-141. Portuguese

15 Szwarcwald CL, Carvalho CH. [Estimate of the number of people infected aged 15-49 years infected by HIV, Brazil, 2000]. Epidemiol Bull AIDS [Internet]. 2001 [cited 2015 Aug 03];14(1). Available from: http://www.aids.gov.br/sites/default/files/Boletim_Epidemiologico_2001_I_Aids.pdf. Portuguese

16 Asamoah-Odei E, Garcia Calleja JM, Boerma JT. HIV prevalence and trends in sub-Saharan Africa: no decline and large subregional differences. Lancet 2004;364(9428):35-40

17 Schwartländer B, Stanecki KA, Brown T, et al. Country-specific estimates and models of HIV and AIDS: methods and limitations. AIDS 1999;13(17):2445-2458

18 Brown T, Bao L, Eaton JW, et al. Improvements in prevalence trend fitting and incidence estimation in EPP 2013. AIDS 2014;28 (Suppl 4):S415-S425

19 World Health Organization. Joint United Nations Programme on HIV/AIDS [Internet]. Guidelines for second-generation HIV surveillance: the next decade. Geneva: UNAIDS/WHO; 2000 [cited 2015 Apr 14]. (UNAIDS/WHO document WHO/CDS/CSR/EDC/ 2000.5, UNAIDS/00.03E). Available from: http://www.who.int/ hiv/pub/surveillance/en/cds_edc_2000_5.pdf

20 United Nations General Assembly Special Sessions on HIV/AIDS [Internet]. Monitoring the Declaration of Commitment on HIV/ AIDS: guidelines on construction of core indicators. Geneva: Joint United Nations Program on HIV/AIDS; 2002 [cited 2015 May 15]. Available from: http://www.who.int/hiv/strategic/me/ en/isbn9291732389.pdf

21 Zaba B, Boerma T, White R. Monitoring the AIDS epidemic using HIV prevalence data among young women attending antenatal clinics: prospects and problems. AIDS 2000;14(11):1633-1645

22 Brazilian Ministry of Health. Health Surveillance Secretariat. Department of DST, AIDS, and Viral Hepatitis [Internet]. [PCAP: Knowledge, Attitudes and Practices among Brazilian Population aged 15 to 64 years - 2008]. Brasília: Ministry of Health; 2011 [cited 2016 Jan 20]. Available from: http://www.aids.gov.br/sites/ default/files/anexos/publicacao/2009/40352/ pcap_2008_f_pdf_13227.pdf. Portuguese

23 Pan American Health Organization [Internet]. 2014 update: elimination of mother-to-child transmission of HIV and syphilis in the Americas. Washington (DC): PAHO; 2014 [cited 2014 Dec 20]. Available from: http://www.unicef.org/lac/Elimination_MTCT_in_the_Americas_2014_ENG.pdf

24 Pan American Health Organization [Internet]. Field guide for implementation of the strategy and plan of action for elimination of mother-to-child transmission of HIV and congenital syphilis in the Americas. Washington (DC): PAHO; 2014 [cited 2015 Feb 18]. Available from: http://iris.paho.org/xmlui/bit- stream/handle/123456789/6080/index.pdf?

sequence $=1$ \&isAllowed $=y$

25 da Cruz Gouveia PA, da Silva GA, de Fatima Pessoa Militão de Albuquerque M. Factors associated with mother-to-child transmission of the human immunodeficiency virus in Pernambuco, Brazil, 2000-2009. Trop Med Int Health 2013;18(3):276-285

26 de Lemos LM, Lippi J, Rutherford GW, et al. Maternal risk factors for HIV infection in infants in northeastern Brazil. Int J Infect Dis 2013;17(10):e913-e918

27 de Andrade SD, Sabidó M, Marcelo Monteiro W, Canellas L, Prazeres V, Schwartz Benzaken A. Mother-to-child transmission of HIV from 1999 to 2011 in the Amazonas, Brazil: risk factors and remaining gaps in prevention strategies. Pediatr Infect Dis J 2016; 35(2):189-195

28 Tornatore M, Gonçalves CV, Mendoza-Sassi RA, et al. HIV-1 vertical transmission in Rio Grande, Southern Brazil. Int J STD AIDS 2010;21(5):351-355

29 Brazilian Ministry of Health. Secretariat of Health Surveillance. Department of STI, Aids and Viral Hepatitis [Internet]. [Recommendations for the prevention of vertical transmission of HIV and antiretroviral therapy in pregnant women-2006] [cited 2015 Sep 15]. Brasília (DF): Ministry of Health; 2007. Available from: http:// bvsms.saude.gov.br/bvs/publicacoes/consenso_gestantes_2007. pdf. Portuguese

30 Domingues RM, Szwarcwald CL, Souza PR Jr, Leal MdoC. Prenatal testing and prevalence of HIV infection during pregnancy: data from the "Birth in Brazil" study, a national hospital-based study. BMC Infect Dis 2015; 15:100

31 Saphonn V, Hor LB, Ly SP, Chhuon S, Saidel T, Detels R. How well do antenatal clinic (ANC) attendees represent the general population? A comparison of HIV prevalence from ANC sentinel surveillance sites with a population-based survey of women aged 15-49 in Cambodia. Int J Epidemiol 2002;31(2):449-455

32 Kharsany AB, Frohlich JA, Yende-Zuma N, et al. Trends in HIV prevalence in pregnant women in rural South Africa. J Acquir Immune Defic Syndr 2015;70(3):289-295

33 do Carmo Leal M, da Silva AA, Dias MAB, et al. Birth in Brazil: national survey into labour and birth. Reprod Health 2012;9:15

34 Eaton JW, Rehle TM, Jooste S, et al. Recent HIV prevalence trends among pregnant women and all women in sub-Saharan Africa: implications for HIV estimates. AIDS 2014;28(Suppl 4):S507-S514

35 Mujugira A, Heffron R, Celum C, Mugo N, Nakku-Joloba E, Baeten JM; Partners PrEP Study Team. Fertility intentions and interest in early antiretroviral therapy among East African HIV-1-infected individuals in serodiscordant partnerships. J Acquir Immune Defic Syndr 2013;63(1):e33-e35

36 Eaton JW, Johnson LF, Salomon JA, et al. HIV treatment as prevention: systematic comparison of mathematical models of the potential impact of antiretroviral therapy on HIV incidence in South Africa. PLoS Med 2012;9(7):e1001245

37 Glynn JR, Buvé A, Caraël M, et al; Study Group on Heterogeneity of HIV Epidemics in African Cities. Factors influencing the difference in HIV prevalence between antenatal clinic and general population in sub-Saharan Africa. AIDS 2001;15(13):1717-1725 